\title{
Submergence Analysis Using Geo-Informatics Technology for Proposed Dam Reservoirs of Par-Tapi-Narmada River Link Project, Gujarat State, India
}

\author{
Khalid Mehmood1, Ajay Patel1, Vijay Singh1, Sumit Prajapati1, Manik Hari Kalubarme1, \\ Indra Prakash ${ }^{*}$, Keshav Prasad Gupta ${ }^{2}$ \\ ${ }^{1}$ Bhaskarcharya Institute for Space Applications and Geo-Informatics (BISAG), Department of Science \& \\ Technology, Government of Gujarat, Gandhinagar, India \\ ${ }^{2}$ National Water Development Agency (NWDA), Valsad, India \\ Email: ${ }^{\text {indraprakash52@yahoo.co.in, kpgupta1962@gmail.com }}$
}

Received 11 March 2014; revised 9 April 2014; accepted 5 May 2014

Copyright @ 2014 by authors and Scientific Research Publishing Inc.

This work is licensed under the Creative Commons Attribution International License (CC BY).

http://creativecommons.org/licenses/by/4.0/

(c) (7) Open Access

\section{Abstract}

The Par-Tapi-Narmada river link envisages transfer of surplus water from west flowing rivers between Par and Tapi in Gujarat State, India to water deficit areas in North Gujarat. The scheme is located mainly in southern Gujarat but it also covers part of the areas of Maharashtra, North of Mumbai on the Western Ghats of India. The main aim of Par-Tapi-Narmada link is to transfer the surplus waters of Par, Auranga, Ambica and Purna River basins to take over part of Narmada Canal command (Miyagam branch) after providing enroute irrigation. It is proposed that water saved in Sardar Sarovar Project, as a result of this transfer, would be taken further northwards to benefit water scarce areas of north Gujarat and also westwards in Saurashtra and Kutch regions. The construction of seven reservoirs on Par-Tapi-Narmada River Link Project would affect land use/land cover, settlements and infrastructure facilities within and around reservoir area. Thus, the submergence impact analysis of all the seven reservoirs of this project have been carried out by using remote sensing and GIS techniques for planning and designing of the structures. Out of the seven reservoirs, the paper discusses submergence analysis of Kelwan Dam reservoir which is located in geologically complex region of the Dangs district. The study attempts to assess the present problems of submergence of land, forest, agriculture, settlements and infrastructure facilities by using

"Corresponding author.

How to cite this paper: Mehmood, K., et al. (2014) Submergence Analysis Using Geo-Informatics Technology for Proposed Dam Reservoirs of Par-Tapi-Narmada River Link Project, Gujarat State, India. International Journal of Geosciences, 5, 622633. http://dx.doi.org/10.4236/ijg.2014.56057 
GIS techniques for taking alternative remedial measures prior and during construction of the dams.

\title{
Keywords
}

\author{
Par-Tapi-Narmada Link Project, Land Use/Land Cover Classification, Submergence Analysis, GIS \\ Environment, Indian Remote Sensing Satellite (IRS) LISS-IV Digital Data
}

\section{Introduction}

The National Water Policy of Government of India lays emphasis on inter-basin transfer of water for conserving and better utilization of monsoon flood-waters during scarcity period for drinking, industrial use, irrigation and power generation. The Par-Tapi-Narmada link envisages transfer of surplus water from west flowing rivers between Par and Tapi located in South Gujarat to water deficit areas in North Gujarat. The scheme is located mainly in southern Gujarat but it also covers part of the areas of Maharashtra, North of Mumbai on the Western Ghats of India. The main aim of Par-Tapi-Narmada link is to transfer the surplus waters of Par, Auranga, Ambica and Purna river basins to take over part of Narmada Canal command (Miyagam branch) after providing enroute irrigation. It is proposed that water saved in Sardar Sarovar Project, as a result of this transfer, would be taken further northwards to benefit water scarce areas of north Gujarat and also westwards in Saurashtra and Kutch regions.

The Par-Tapi-Narmada River link mainly envisages construction of seven dams, three diversion weirs, two tunnels ( $5.0 \mathrm{~km} \& 0.5 \mathrm{~km}$ of length), $395 \mathrm{~km}$ long canal (205 km in Par-Tapi reach including the length of feeder canals and $190 \mathrm{~km}$ in Tapi-Narmada reach), six power houses and a number of cross-drainage works. Besides providing irrigation benefits to the enroute Par-Tapi command and Narmada command, the link will generate hydropower of the order of $93 \mathrm{MkWh}$ through the power houses to be installed at four proposed dam sites viz. Jheri, Paikhed, Chasmandva and Chikkar and in two feeder canals to be off take from Dabdar and Kelwan dams.

\subsection{Proposed Dams}

The seven proposed dams in the scheme are Jheri, Mohankavchali, Paikhed, Chasmandva, Chikkar, Dabdar and Kelwan. The Jheri and Mohankavchali dams would be constructed across Par River, one below the other while the Paikhed dam across Nar River, a tributary of the Par. Chasmandva dam would be across Tan River, a tributary of Auranga River, Chikkar dam across Ambica River, Dabdar across Kapri River which is Ambica's tributary and Kelwan dam across Purna River. Water from Jheri dam would reach Mohankavchali reservoir after power generation.

Three diversion weirs would be constructed one each in the downstream of Paikhed, Chasmandva and Chikkar dams. The water from Mohankavchali reservoir would flow through a $5 \mathrm{~km}$ long tunnel to reach the Paikhed weir. The first part of the link canal viz Par-Tapi reach would off take from the right bank of the Paikhed weir and after inter-connecting the remaining four reservoirs viz Chasmandva, Chikkar, Dabdar and Kelwan would finally terminate at the left flank of existing Ukai reservoir on Tapi river. The second part of the link canal viz. Tapi-Narmada reach would off take from the right bank of Ukai reservoir and after crossing the Narmada river in the downstream of Sardar Sarovar reservoir. The Tapi-Narmada canal finally joins the Miyagam branch canal at R.D. $16.7 \mathrm{~km}$ after traversing a length of $190.14 \mathrm{~km}$. The FSL of link canal is $54.38 \mathrm{~m}$ at the terminal point whereas FSL of Miyagam branch canal is $53.36 \mathrm{~m}$ [1].

\subsection{Utility of Submergence Analysis}

Construction of seven reservoirs of Par-Tapi-Narmada Link Project would affect land use/land cover, settlements and infrastructure facilities within and around reservoir area. Thus submergence impact analysis of all the seven reservoirs of this project have been carried out using remote sensing and GIS techniques for planning and designing of the structures. Out of the seven reservoirs, the paper discusses submergence analysis of Kelwan Dam reservoir which is located in geologically complex area of the Dang district. The technique adopted for all other reservoirs is almost similar. 


\section{Objectives}

The Par-Tapi-Narmada Link Project of the National Water Development Agency (NWDA) was undertaken at Bhaskaracharaya Institute for Space Applications and Geo-informatics (BISAG), with following major objectives:

1) Generation of various Thematic Maps using Indian Remote Sensing Satellite (IRS) LISS-IV digital data;

2) Generation of contours of $5 \mathrm{~m}$ interval using DEM at above and below full reservoir level;

3) Visualization of submergence extent at Full Reservoir Level (FRL);

4) Comparison of submergence areas based on ground survey;

5) Generation of detailed area statistics on submerged areas at different FRLs for different Land use classes.

\section{Study Area}

The project area of Par-Tapi-Narmada Link project comprises of areas starting from Valsad, Navsari, the Dangs, Surat Tapi, Narmada, Bharuch, and Vadodara districts. The most of the project area falls in the state of Gujarat except Jheri reservoir which falls in Maharashtra state. Jheri dam is located in Nasik district of Maharashtra, while remaining dams viz. Mohankavchali, Paikhed, Chasmandva, Chikkar, Dabdar and Kelwan dams are located in Valsad and Dang districts of Gujarat (Figure 1).

Par-Tapi reach of canal passes through Valsad, Navsari, Dangs and Surat districts of South Gujarat whereas Tapi-Narmada reach of canal passes through Surat, Bharuch and Vadodara districts of Gujarat. Thus, the project area is mainly spread in the districts of South Gujarat except for Jheri dam and reservoir. However, the irrigation benefits of this scheme would ultimately reach Saurashtra and Kutch regions of Gujarat after providing enroute irrigation in the specified commands of Par-Tapi and Tapi-Narmada reaches of the link.

\subsection{River Systems in the Area}

The area is drained by westerly flowing rivers, namely Narmada, Tapi, Damanganga, Auranga, Ambica, Par, and their tributaries. The Par-Tapi River project is linked with a canal system passing through Par, Auranga, Ambica, Purna, Mindhola, Tapi and Narmada basins. The Par River is one of the important west flowing rivers south of the Tapi River in the region. The river rises in the Sahyadri hill ranges at an elevation of about $1100 \mathrm{~m}$ above mean sea level in Nasik district of Maharashtra state and traverses a distance of $131 \mathrm{~km}$ before draining into the Arabian Sea. One diversion point viz. Mohankavchali has been identified across Par River for a hydroelectric project. Another site has also been identified at Jheri in the upstream of Mohankavchali site on Par River. The Nar River is a northen tributary of Par River. The Nar River rises at an altitude of 980 metres in the Sahyadri hill ranges in Surgana taluka of Nasik district in the state of Maharashtra.

Like the Par, the Auranga is also one of the important west flowing rivers in the region north of Mumbai City and south of Tapi River. The river is known as Auranga after the confluence of its two tributaries the Man and

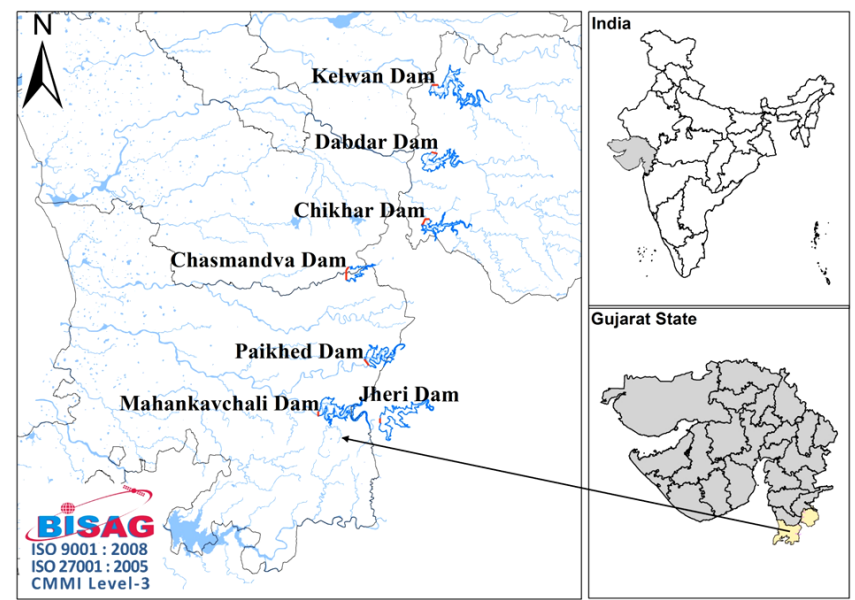

Figure 1. Location map of the Par-Tapi-Narmada river link dam projects in Gujarat. 
the Tan. Both tributaries originate in the Sahyadri hill ranges in the Nasik district of Maharashtra state. The river traverses a distance of about $30 \mathrm{~km}$ from confluence of the tributaries before draining into the Arabian Sea. The Auranga basin extends over an area of $787 \mathrm{sq} \mathrm{km}$, out of which $150 \mathrm{sq} \mathrm{km}$ is in Maharashtra state and $637 \mathrm{sq} \mathrm{km}$ is in Gujarat state. The Ambica is a west flowing river rises in the Sahyadri hill ranges in the Nasik district of Maharashtra state at an elevation of about $1050 \mathrm{~m}$ above M.S.L. and after traversing a total distance of $164 \mathrm{~km}$ joins the Arabian Sea in the state of Gujarat. The basin extends over an area of $2830 \mathrm{sq} \mathrm{km}$ out of which $102 \mathrm{sq}$ $\mathrm{km}$ lies in Maharashtra while $2728 \mathrm{sq} \mathrm{km}$ is in Gujarat. Two diversion points proposed in Ambica basin are, one across river Kapri near village Dabdar and the other across river Ambica near village Chikkar.

The river Purna is also a west flowing river, it originates in the Sahyadri hill ranges of the Western Ghats at an elevation of about $1300 \mathrm{~m}$ in the Ahwa taluka of Dang district in the state of Gujarat and after traversing a distance of $180 \mathrm{~km}$, it outfalls into the Arabian sea. The important tributaries of the Purna River are Girra, Jankhari and Damaskhadi rivers. One diversion point has been identified in the basin near village Kelwan across the river Purna. The level of the river bed drops steeply from $1300 \mathrm{~m}$ at source to about $115 \mathrm{~m}$ at the dam site. The entire area lies in Gujarat state. The river Mindhola is a small west flowing river with its catchment lying entirely in Gujarat state.

The river Tapi is the second largest west flowing inland river of the peninsula rises near Betul district of Madhya Pradesh at an elevation of $752 \mathrm{~m}$. The Tapi basin extends over an area of 65,145 sq km and is situated in the Deccan plateau. The basin covers a drainage area of $9804 \mathrm{sq} \mathrm{km}$ in Madhya Pradesh, 51,504 sq km in Maharashtra and $3837 \mathrm{sq} \mathrm{km}$ in Gujarat. The important tributaries joining from the left are the Purna, the Vaghur, the Girna, the Bori, the Panjhra and from the right the Aner. The drainage area of the Tapi basin upto Ukai dam is 62,225 sq km of which $9804 \mathrm{sq} \mathrm{km}$ in Madhya Pradesh, 51,504 sq km in Maharashtra and $917 \mathrm{sq} \mathrm{km}$ in Gujarat. The Narmada is the longest west flowing river in India. It is the fifth largest river in the country and the largest one in Gujarat. It originates at Amarkanthak Hill in Madhya Pradesh and joins the Gulf of Khambat in the Arabian Sea. The total length of the river from source to sea is about $1312 \mathrm{~km}$.

\subsection{Physiography of the Area}

Physiographically, western part of the project area is plain whereas central, eastern and northern part is characterized by the rugged hilly terrain. Physiography of the individual river basins is as below.

\subsubsection{Par and Auranga Basins}

The Par and Auranga basins consist of five main physiographic units namely:

1) Hill tops and hill slopes;

2) Hill terraces and plateaus (up lands);

3) Upper and lower foot slopes (medium lands);

4) Valley plains and local depressions (low lands) and;

5) River and stream banks.

\subsubsection{Ambica Basin}

The Ambica basin can be divided into two prominent eastern and western part physiographic zones. The eastern part is a rugged mountain chain of the Sahyadri which descends western side to the edge of the uplands of Surat district. This region is situated at a general elevation ranging from $1050 \mathrm{~m}$ to $100 \mathrm{~m}$.

\subsubsection{Purna Basin}

The Purna basin can be divided into three prominent physiographic regions namely: 1) Eastern parts, 2) Middle reaches and 3) Coastal zones. The eastern parts of the basin cover a chain of rugged mountain ranges of the Western Ghats running at an elevation of above $1300 \mathrm{~m}$ and descending to an elevation of about $100 \mathrm{~m}$ at the edges of uplands of the Surat district. The middle reaches of the basin area marked by high relief zone with ridges and valleys. The hilly zone then merges into the plains through an undulating piedmont coastal zone running parallel to the sea.

\subsubsection{Mindhola Basin}

The Mindhola basin can be divided into three sections. The first $25 \mathrm{~km}$ reach drains the areas of uplands where 
the elevation is between $400 \mathrm{~m}$ to $70 \mathrm{~m}$. In the middle section, the river passes through both steep and moderate slopes. The general elevation of the basin in this section is from $70 \mathrm{~m}$ to $5 \mathrm{~m}$. The remaining portion of the basin in the west is subject to inundation in high tides of the sea.

\subsubsection{Tapi Basin}

The Tapi basin is bounded on the north by the Satpura range, on east by the Mahadeo hills, on the south by the Ajanta range and the Satmala hills and on the west by the Arabian Sea. The basin has an elongated shape with a maximum length of $587 \mathrm{~km}$ east to west and maximum width of $201 \mathrm{~km}$ from north to south. The basin has two well-defined physical regions, viz. the hilly region and the plains. The hilly region covers the Satpuras, the Satmalas, the Ajanta and the Gawilgarh hills.

\subsubsection{Narmada Basin}

The Narmada basin is bounded on the north by the Vindhyas, on the east by the Maikalu range, on the south by the Satpuras and on the west by the Arabian Sea. Physiographically the Narmada Valley is divided into three zones namely "Upper zone" between Bilaspur and Mandla in Madhya Pradesh (M.P.), "Middle zone" between Mandla and East Nimar in M.P. and "Lower zone or Lower Narmada Valley" between East Nimar (M.P.) and Bharuch (Gujarat). In the Lower Narmada Valley, the Narmada River flows in gorge mainly through Deccan Trap basalt and infra-trappean sedimentaries in straight course upto Gora (about 6 km downstream of Narmada dam). The area exhibits faulted block topography with alternating ridges and valleys aligned almost in ENEWSW direction.

\subsubsection{Drainage Pattern in the Study Area}

Drainage pattern in the area is controlled by topography and geological structure. Hilly areas are marked by dendritic drainage. Valleys and near flat areas are marked by sub-parallel to parallel drainage. In some areas, drainage is controlled by faults/lineament aligned in NNW-SSE and ENE-WSW directions. The India Remote Sensing Satellite LISS-IV imagery with major drainage, rivers, location of seven-proposed dams and district boundary are shown in Figure 2.

\subsection{Geology of the Area}

Geology of the different components of the Par-Tapi-Narmada projects varies from Precambrian rocks to Quaternary sediments depending on their locations. The rocks and sediments in the area include Precambrian metamorphites and associated intrusive, Mesozoic sedimentary rocks, Deccan Basalt of Cretaceous to Eocene age, Tertiary sedimentary rocks and marine, fluvial and alluvial deposits of Quaternary age. All the Seven proposed project sites are located mainly on Deccan basalts covered at places by soil and alluvium (Figure 3).

The proposed canal system of the project is passing through varying geology from south to north i.e. Deccan basalt in the central and southern part of the command area in Narmada, Dangs, Valsad and Nasik districts and Aravalli super-group meta-sedimentary rocks associated with granite/granite gneisses in the northern part of the Vadodara district. The Deccan basalt flows are mainly of two types-"Pahoehoe" and "Aa". Intermediate flows are also present at places. Thickness of "Aa" flows in the area varies from $7 \mathrm{~m}$ to $70 \mathrm{~m}$, whereas, "Pahoehoe" flow units are thin varying from $1 \mathrm{~m}$ to $5 \mathrm{~m}$. Top of "Aa” flows is generally marked by agglomerate and red bole layers, whereas, "Pahoehoe" flows are marked by ropy lava and spheroidal vesicles/amygdales at the top and pipe amygdales at the bottom. Mineralogically, flows vary from aphynic to strongly phyric characters with phenocrysts of plagioclase and olivine or clinopyroxene. Weathering is more predominant along the contacts of flows especially in the areas occupied by "Pahoehoe" flows. The Infra-trappean Lameta/Bagh formations comprising of sandstone, limestone and shale occur as inliers in Narmada Valley within Deccan basalts [7].

\section{Methodology}

\subsection{Satellite Data Used}

In the present study, two scenes of IRS-P6 LISS-IV (5.8 m resolution) data of Kharif \& Rabi season (January 2011 to March 2011) have been used for various thematic interpretations. The details of Satellite data used are given in Table 1. For most of the thematic interpretations such as land use/land cover, drainage, water bodies 


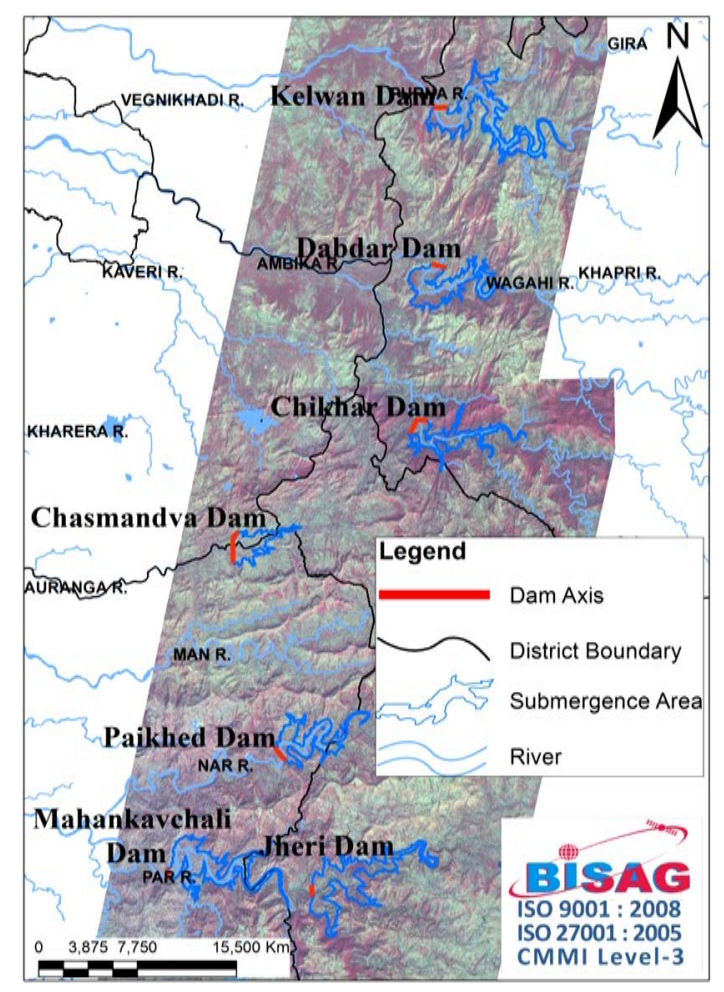

Figure 2. IRS LISS-IV imagery showing locations of Par-Tapi-Narmada link dam projects and topography of the area.

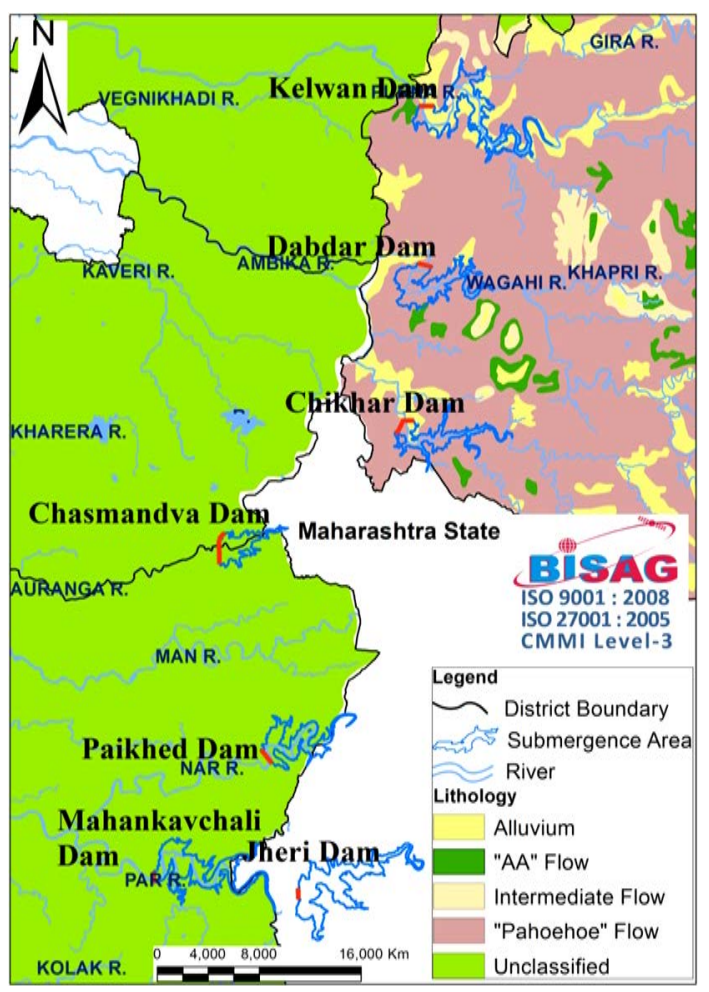

Figure 3. Geological map of Par-Tapi-Narmada link project area (after [2]-[6]). 
Table 1. Indian remote sensing satellite data used in this study.

\begin{tabular}{cccccc}
\hline Satellite (Sensor) & Spectral Bands $(\mu \mathrm{m})$ & Resolution $(\mathrm{m})$ & Swath $(\mathrm{km})$ & Path/Row & Date of Pass \\
\hline IRS-P6 & $0.52-0.69$ & & & & \\
LISS-IV & $0.62-0.68$ & 5.8 & $23 \times 23$ & $203 / 028$ & 28 January 2008 \\
& $0.77-0.86$ & & & & \\
CARTOSAT & $0.5-0.85$ & 2.5 & $27 \times 27$ & $0515 / 0300$ & 31 January 2008 \\
\hline
\end{tabular}

mining related features, high resolution satellite data (Cartosat-1 Pan of 18 March 2007) of 2.5 m resolution has been used. Since the cartosat data is in panchromatic mode, this data is merged with the LISS-IV (MX) data to achieve high resolution (2.5 m resolution) multi-spectral image. This merged data product is extensively used for base map updation of settlement, road, drainage, water bodies etc. Stereo product of cartosat-1 Pan-Aft and Pan-Fore are exclusively used for DEM and Contour generation.

\subsection{Collateral Data}

In this study, base maps of the various dam sites prepared by the National Water Development Authority (NWDA) were used for preparation of various thematic maps.

\subsection{Data Analysis}

The methodology adopted for generation DEM using CARTOSAT data, contour generation at various intervals, generation of thematic maps and visualization of submergence analysis at various FRL levels is as follows:

1) Generation of Digital Elevation Model (DEM) using CARTOSAT DEM of the study area;

2) Generation of contours of $5 \mathrm{~m}$ interval using CARTOSAT DEM data;

3) Generation of various thematic maps like land use/land cover, forest, agricultural land, settlements and infrastructure and submergence area mapping using Indian Remote Sensing Satellite (IRS) LISS-IV digital datal

4) Computation of area statistics under various land use classes with various levels of FRL and submergence.

The IRS LISS-IV image covering Kelwan Dam site along with submergence extent at $164 \mathrm{~m}$ FRL is given in Figure 4.

\subsection{DEM Generation}

Stereo imaging from space-borne platforms offers information about terrain elevation besides supplying spectral reflectance of the scene. This greatly assists the analysis and interpretation of images in terms of identifying slopes, surface material, waterways, vegetation growth etc. A high resolution (2.5 m) CARTOSAT-1 stereo imagery, dated 2 October 2005 (path/row: 0526/0258) having a swath of $27 \mathrm{~km} \times 27 \mathrm{~km}$ was used for the generation of DEM of the area (Figure 5) [8].

The methodology adopted to produce the CartoDEM involved stereo-strip triangulation of $500 \mathrm{~km}$ strip stereo pairs using high precise ground control points [9]. The CartoDEM is a surface model of elevation. The generated DEM was draped on the Indian Remote Sensing Satellite (IRS) LISS-IV digital data for visualization of the extent of flooding with different FRL levels (Figure 6), interactive query and decision making.

\subsection{Contour Generation}

Contours at $5 \mathrm{~m}$ interval were generated from DEM and superimposed on different thematic layers for analysing the extent and type of the land use/land cover, forest, settlement infrastructures, archaeological sites etc. to be submerged at various water levels in the reservoir (Figure 7). This information is being used for the finalization of the Full Reservoir Level. FRL will also depend on the social and techno-economic considerations.

\subsection{Submergence Analysis}

During and after construction of the dam land, forest, agriculture, natural resources, archaeological sites, settlements and infrastructure facilities etc. would be partly or fully submerged depending on the reservoir levels. It is 


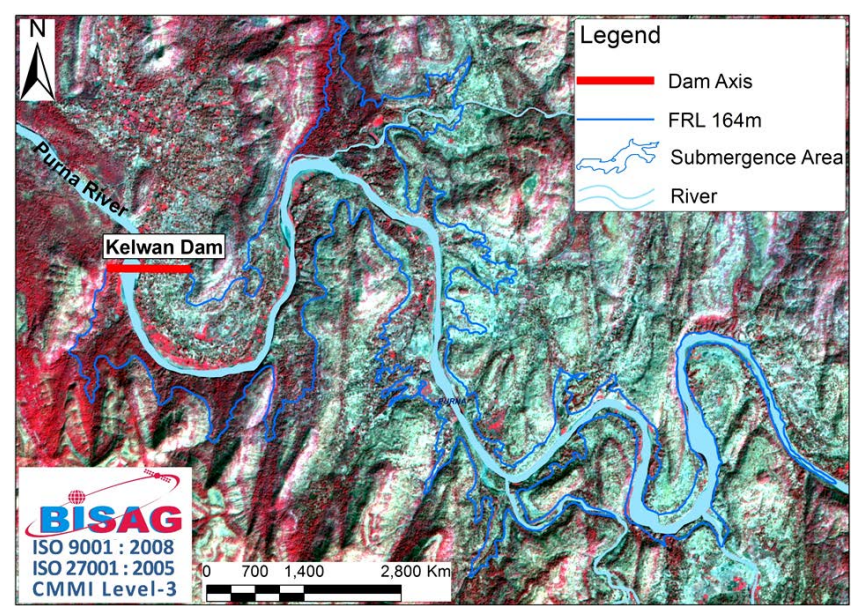

Figure 4. IRS LISS-IV image covering Kelwan dam site in the project area.

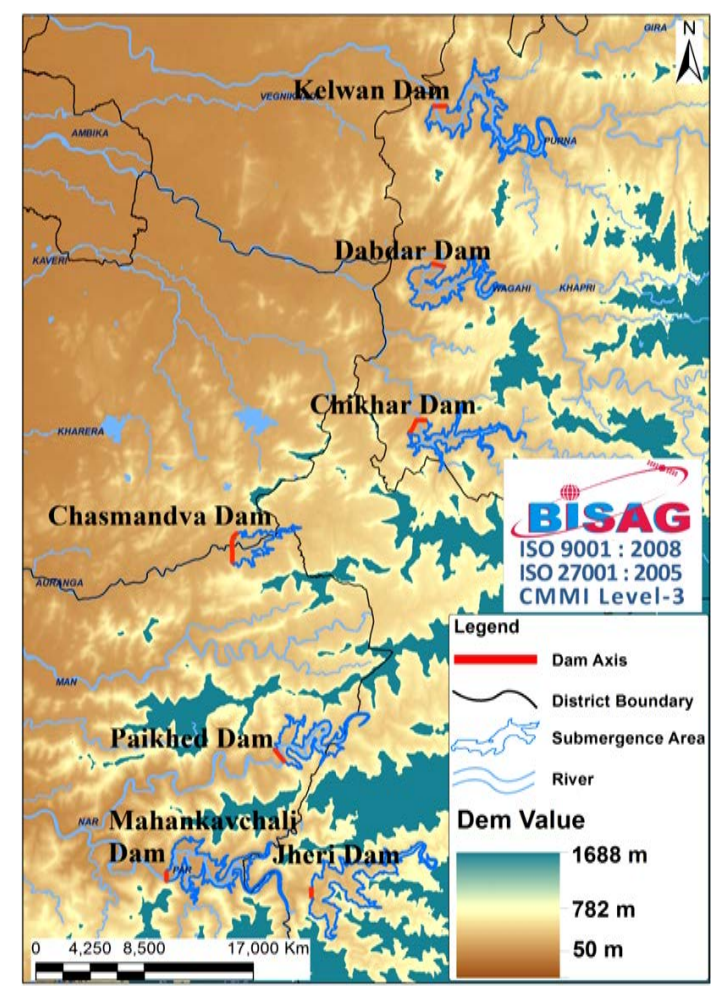

Figure 5. DEM image of Par-Tapi-Narmada link project area.

desirable to carry out submergence study prior to construction of the dam to assess its impact on land use/land cover, society and environment and for planning of relocation of settlement and infrastructures. It also involves seepage/leakage study and sedimentation study of the reservoir.

\subsubsection{Seepage and Leakage Analysis}

Filling of the dam would cause permanent movement (seepage/leakage) of water from the reservoir under and around the dam and along rim of the reservoir through open discontinuities such as joints, faults, shears/fractures/fissures, buried channels, cavernous limestone, lava tunnels etc. [10]. Amount of seepage and leakage would depend on the porosity and permeability of infilling material of discontinuities and their dimensions and 


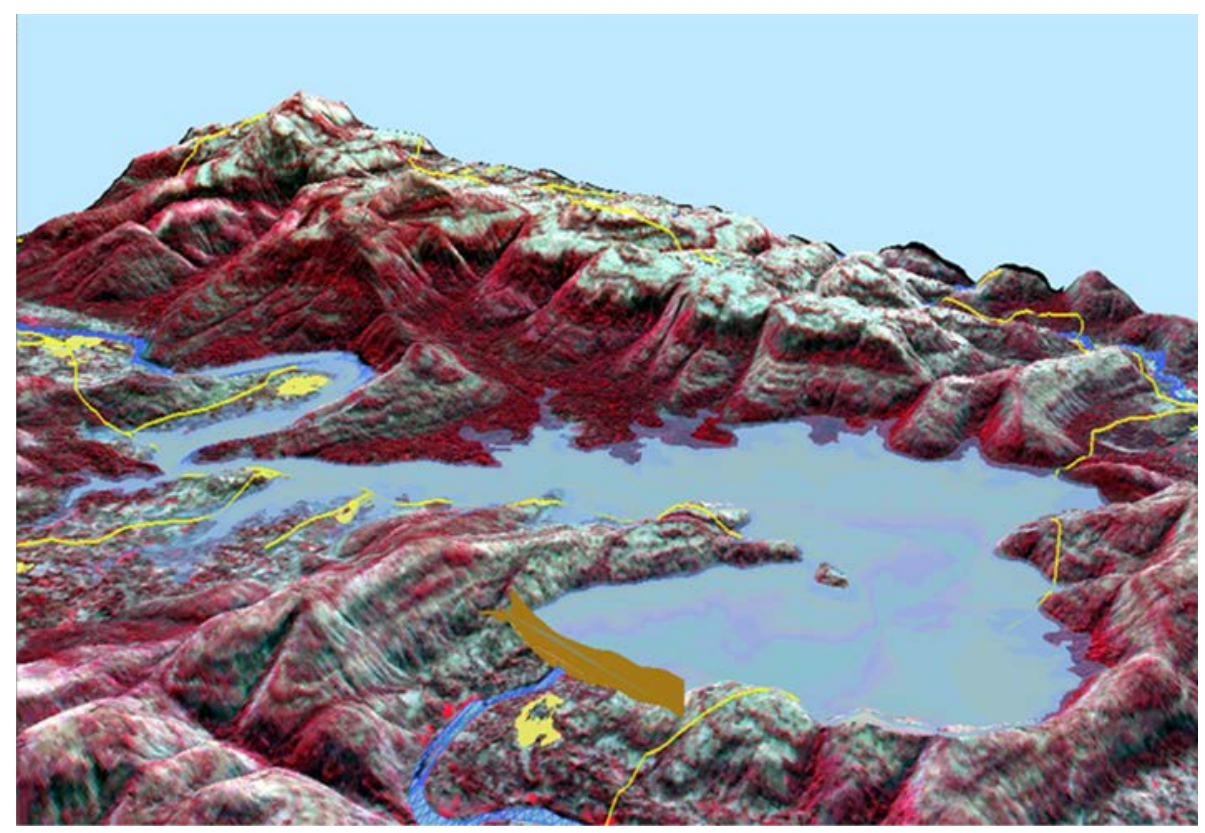

Figure 6. DEM draped on the IRS LISS-IV digital data for visualization of flooding and submergence of infrastructure in the upstream.

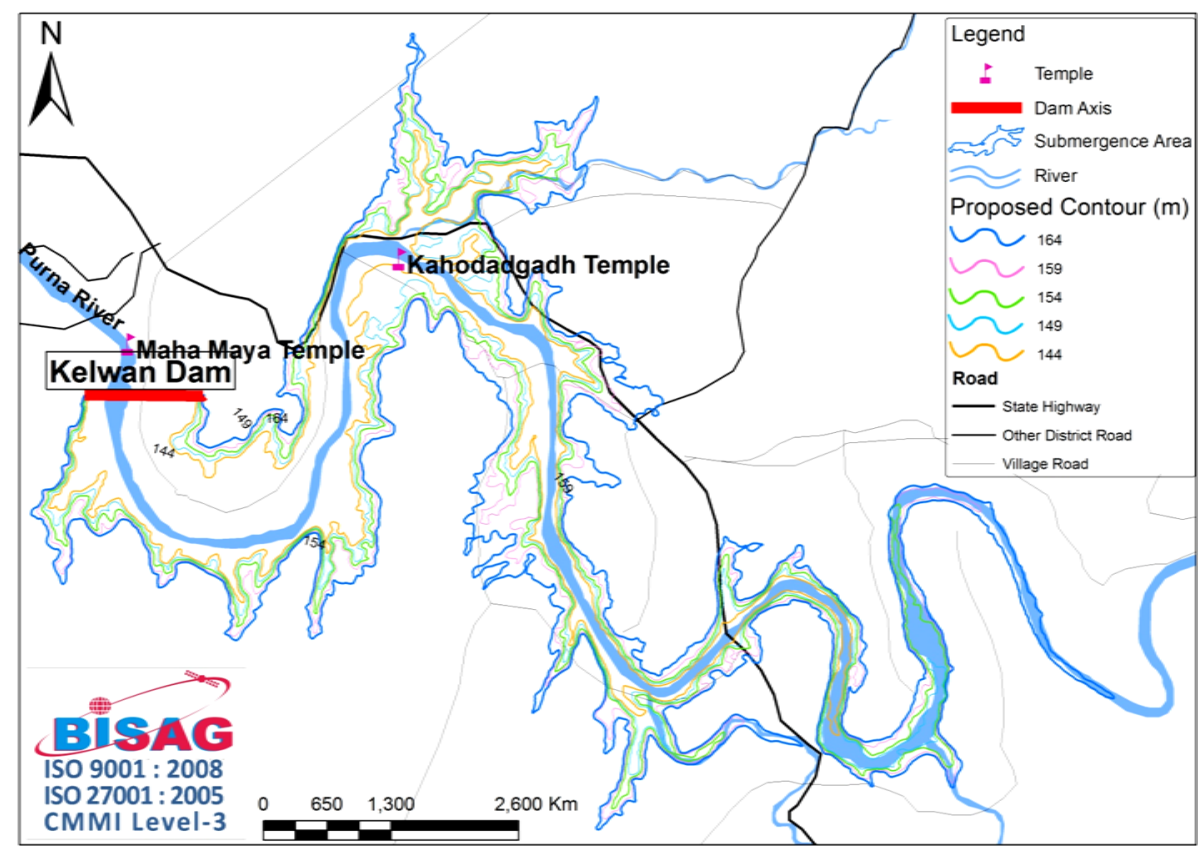

Figure 7. Contours of various FRL and submergence extent.

disposition and also on the water levels of the reservoir. Identification of weak geological features is desirable to evaluate water tightness of the reservoir. Study of the ground water conditions in the area is also essential to assess seepage or leakage through reservoir and rim.

\subsubsection{Sedimentation Study}

Submergence study also involves sedimentation study prior and after filling of the reservoir. Sedimentation depends on the characteristic of the water shed such as soil or rock type, vegetation cover, intensity and duration of precipitation and slope stability. Prior to filing of the reservoir volume of the river valley likely to be submerged 
can be calculated from initial contours of the valley for later estimation of actual sedimentation during operation of the dam. At present site specific geological, geo-hydrological and sedimentation studies are under progress.

In this paper, primarily impact assessment of submergence of reservoirs on infrastructures, land use/land cover and settlements using remote sensing and GIS has been presented.

\subsection{Estimation of Submergence Area at Different Proposed FRLS}

The contours at $5 \mathrm{~m}$ interval starting from $144 \mathrm{~m}$ to $169 \mathrm{~m}$ were generated using CARTOSAT (Stereo) DEM. With the help of dam alignment and Full Reservoir Level (FRL), appropriate contour has been selected through which the submergence can be computed at particular water-level at the dam axis. The contours of different FRL of 144, 149, 154, 159 and $164 \mathrm{~m}$ were generated and superimposed on IRS LISS-IV image and extent of submergence was delineated and area under various land use classes at each dam site was estimated (Figure 7).

\section{Results and Discussions}

\subsection{Generation of Land Use Maps}

In the present study, attempt was made to study the impact of submergence at various FRL levels on various land use categories. The DEM of the study area was generated using the CARTOSAT data. The contours and submergence at various levels of FRL were also generated. Thematic maps of land use/land cover, forest, agricultural land, settlements and various infrastructure facilities were prepared using LISS-IV digital data and GIS software and used in identifying, demarcation and assessment of type of land use/land cover, infrastructure and settlement etc. likely to be affected by submergence under varying storage levels of reservoir water (Figure 8). 3-D digital reservoir models were also generated and used for the submergence analysis of individual sites.

\subsection{Submergence of Land Use Classes at Different Reservoir Levels/FRL}

Indian Remote Sensing Satellite LISS-IV digital data was analyzed for the generation of land use maps. From these maps submerged areas of different land use classes such as plantations, forest, agricultural land and settlements at different reservoir levels/proposed FRL were computed and the area statistics of these classes of all the seven dams were generated. As the methodology is almost similar, area statistics of one of the dam site (Kelwan dam) under submergence is discussed (Figure 9).

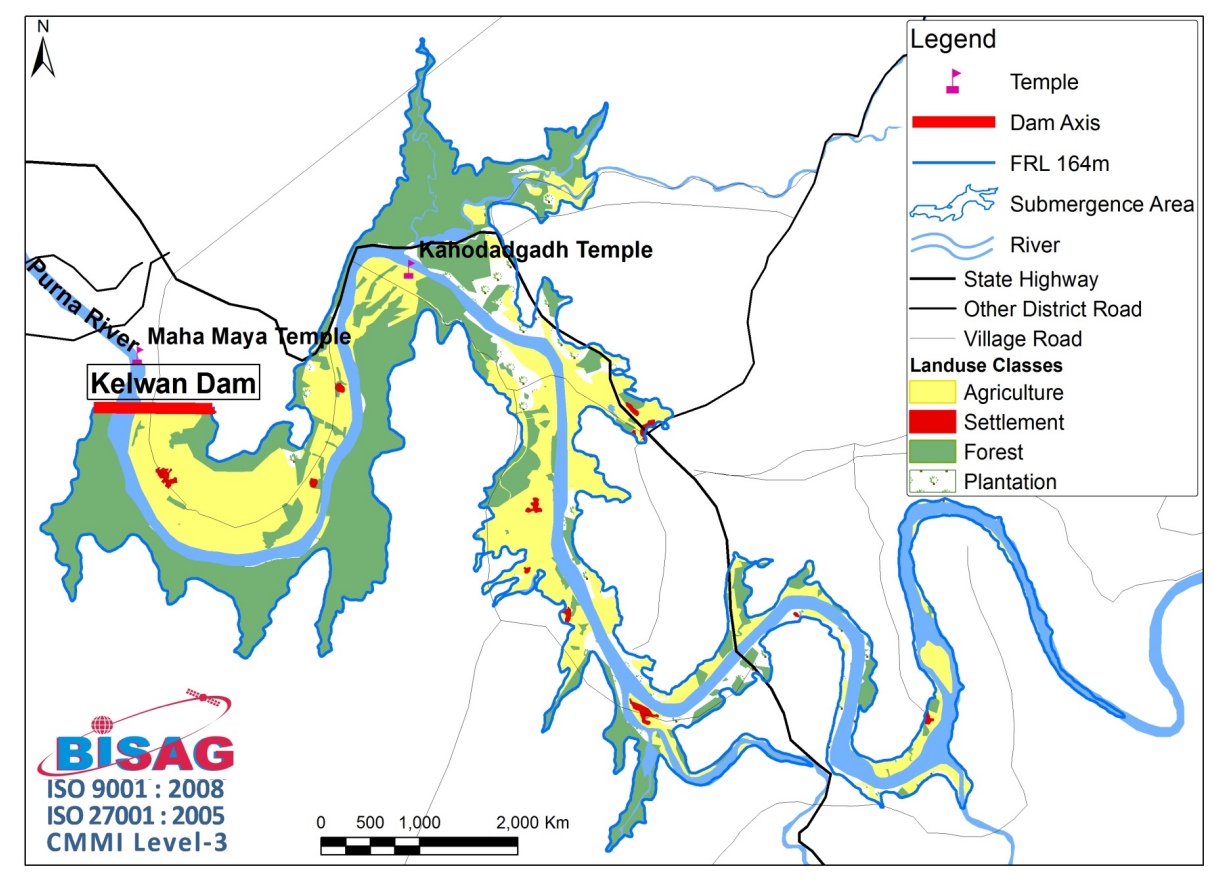

Figure 8. Land use map of Kelwan dam site generated from IRS LISS-IV digital data. 
It was observed from the submergence statistics that with increasing proposed FRL levels the submergence area increases appreciably for example, Agriculture (238 to 511 ha.), Natural Forest (194 to 699 ha) and Plantation (24 to $122 \mathrm{ha}$ ) whereas minor increase was observed in settlement class (4 to $12 \mathrm{ha}$ ) indicating that there is not much variation in submergence of habitation pattern in the area.

\subsection{Estimation of Submergence Area of Settlements at Proposed FRLs}

The submergence of villages around the dam site with increasing water levels was also studied along with the area of individual village getting submerged at various levels of proposed FRL. It was estimated in terms of percentages. This statistics helped in identifying various settlements likely to be affected and thus required to be relocated.

Analysis of submergence area of Kelwan dam indicated that Bhondya and Engnipada (Kolbari) villages would be totally submerged at and above proposed FRL $144 \mathrm{~m}$. Similarly Wankan and Pandharma villages would be totally submerged at and above FRL $154 \mathrm{~m}$ and $164 \mathrm{~m}$, respectively. There would be no submergence of Pandharma and Kalibal villages at and below FRL $159 \mathrm{~m}$ as they are located beyond fringe of reservoirs (Table 2).

\subsection{Identification of Individual Agricultural Plots under Submergence}

Analysis of agriculture land for each village at each dam site was done to identify individual survey numbers likely to be submerged at various proposed FRLs. Thematic maps showing reservoir boundaries at proposed FRLs of each dams were prepared showing survey numbers of agricultural plots. As an example, analysis of individual agricultural plots under submergence at Kelwan dam has been prepared (Figure 10). This will help in identifying affected agricultural land owners for proper relocation/compensation and thus in decision making.

\section{Conclusions}

Submergence impact analysis of the proposed seven dams of Par-Tapi-Narmada Link Project was carried out using Remote Sensing and GIS techniques. The Par-Tapi-Narmada link envisages transfer of surplus water from west flowing rivers between Par and Tapi to water deficit areas in North Gujarat. Construction of seven reser-

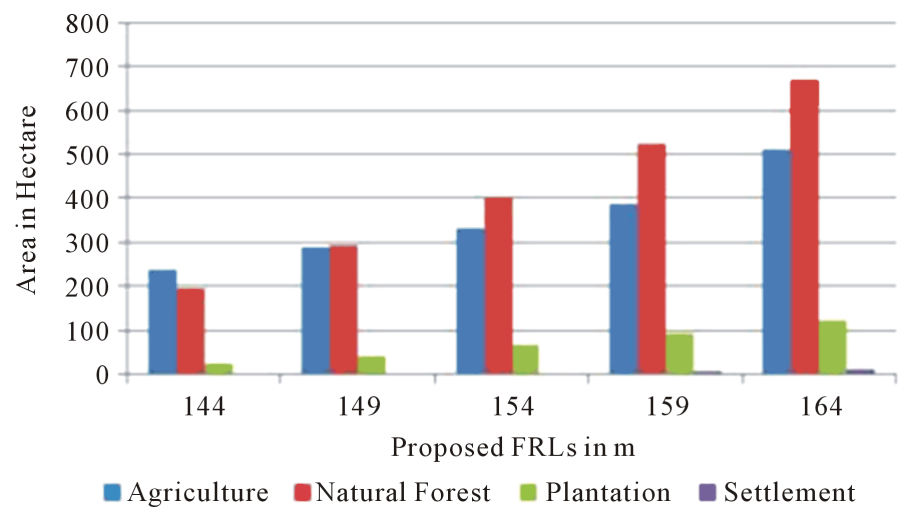

Figure 9. Submergence of various land-use classes at various FRLs of Kelwan dam.

Table 2. Percentage of area of villages submerged at various proposed FRLs at Kelwan.

\begin{tabular}{|c|c|c|c|c|c|}
\hline FRL (m) & Bhondya & Eninpada & Wankan & Pandharma & Kalibel \\
\hline 164 & 100 & 100 & 100 & 100 & 35 \\
\hline 159 & 100 & 100 & 100 & 0 & 0 \\
\hline 154 & 100 & 100 & 100 & 0 & 0 \\
\hline 149 & 100 & 100 & 95 & 0 & 0 \\
\hline 144 & 100 & 100 & 35 & 0 & 0 \\
\hline
\end{tabular}




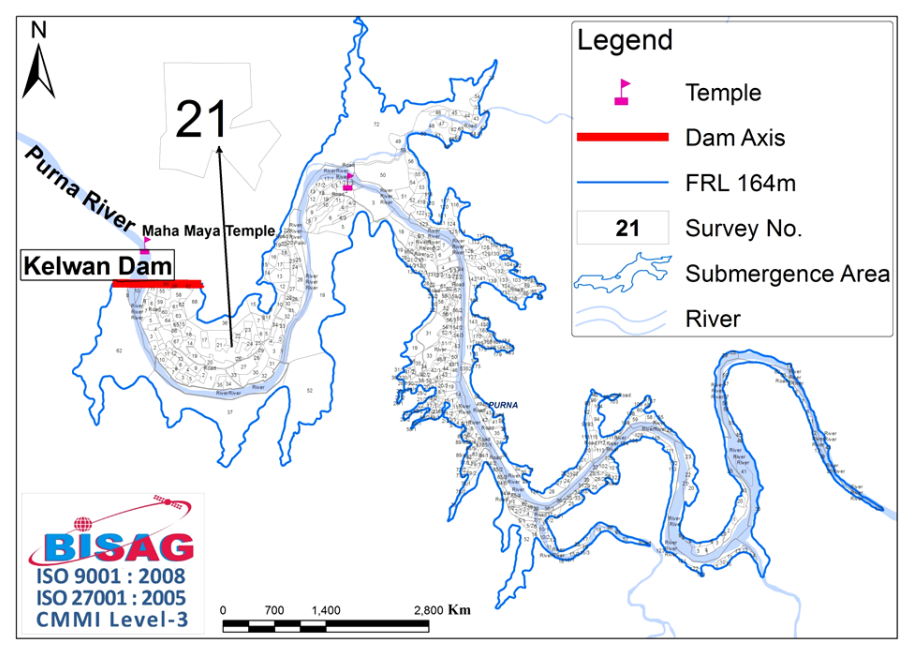

Figure 10. Submergence of agricultural survey numbers at various FRLs.

voirs of Par-Tapi-Narmada Link Project would affect land use/land cover, settlements and infrastructure facilities within and around reservoir area.

Various thematic maps were generated using Indian Remote Sensing Satellite (IRS) LISS-IV digital data. DEMs of reservoir were prepared for the visualization and decision making. The study attempts to assess the present problems of submergence for taking alternative remedial measures prior and during construction of the dams to fix the FRL and for planning of relocation of settlement, archaeological site and infra structures.

In this project, various technologies like photogrammetry, GIS, image processing and Management Information System (MIS) have been utilized for preparation of Detailed Project Report (DPR) at field-level. All these technologies have been integrated for submergence analysis at BISAG. These technologies have resulted in considerable saving in terms of time and cost required for detailed field surveys.

\section{Acknowledgements}

The authors express their sincere thanks to Shri T. P. Singh, Director, Bhaskarcharya Institute for Space Applications and Geo-Informatics (BISAG), Department of Science \& Technology, Government of Gujarat, Gandhinagar for his encouragement and guidance to conduct this study and technical support and facilities provided by Shri M. K. Srinivas, Chief Engineer (South), NWDA, Hyderabad.

\section{References}

[1] NWDA (2013) Feasibility Report of Par-Tapi-Narmada Link Project. https://NationalWaterDevelopmentAgency.gov.in/

[2] GSI (2007) District Resource Map of Vadodara District, Gujarat. Geological Survey of India Publication, Kolkata.

[3] GSI (2007) District Resource Map of Rajpila District, Gujarat. Geological Survey of India Publication, Kolkata.

[4] GSI (2002) District Resource Map of Dang District, Gujarat. Geological Survey of India Publication, Kolkata.

[5] GSI (2002) District Resource Map of Surat District, Gujarat. Geological Survey of India Publication, Kolkata.

[6] GSI (2000) District Resource Map of Valsad District, Gujarat. Geological Survey of India Publication, Kolkata.

[7] Prakash, I. (2013) Geotechnical Evaluation of Major Dams in Lower Narmada Valley in Gujarat State. Geological Survey of India, Bulletin: Series-B, 64, 1-106.

[8] Singhi, V.K., et al. (2010) Orthorectification and Digital Elevation Model (DEM) Generation Using Cartosat-1 Satellite Stereo Pair in Himalayan Terrain. Journal of Geographic Information System, 2, 85-92. http://dx.doi.org/10.4236/jgis.2010.22013

[9] Bharadwaj, A. (2013) Use of DEM in Visualization and Decision Making. American Journal of Remote Sensing, 1, 1-6.

[10] Krynine, D.P. and Judd, W.R. (1957) Principals of Engineering Geology and Geotechnics. McGraw-Hill Book Company, Inc., New York, 1-707. 